\title{
Depression, Anxiety, and Stress in University Students: Effects of Dysfunctional Attitudes, Self-Esteem, and Age
}

\author{
Esra Asici - Halil Ibrahim Sari* \\ Received: September 30, 2020; received in revised form: January 15, 2021; \\ accepted: January 18, 2021
}

\begin{abstract}
:
Introduction: This study aimed to investigate the direct and indirect effects of dysfunctional attitudes (perfectionism and dependency) and age on depression, anxiety, and stress and the mediator role of self-esteem in these relationships in undergraduate university students.

Methods: This study was designed as a relational study to examine the relationships between dysfunctional attitudes, depression, anxiety, stress, self-esteem, and age using path analysis technique. The participants consisted of 407 undergraduate university students, 287 females and 120 males. The data were collected using the Depression, Anxiety, Stress Scale (DASS-21), the short form of the Dysfunctional Attitudes Scale (DAS-17), the Rosenberg Self-esteem Scale, and Demographic Information Form.

Results: The findings showed that perfectionism positively affected the participants' depression and stress levels; however, direct effect of the perfectionism on anxiety was not significant at the alpha level of .05. Dependency directly and positively affected their stress level; however, it did not have a significant effect on their depression and anxiety levels. Self-esteem and age directly and negatively affected their depression, anxiety, and stress levels. Perfectionism and dependency negatively affected their self-esteem. Finally, dependency positively affected their depression, anxiety, and stress levels through the mediation of self-esteem.

Discussion: The findings showed that the students with high self-esteem would stay away from depression, anxiety, and stress. University students, who want to be flawless in all tasks and to be approved by others, have difficulties in making positive judgments about their selves. When the perfectionist and dependent students face difficulties, they may react emotionally, physically or behavioraly, and may feel disappointed, unhappy, guilty or depressed. The students who lose self-esteem, selfconfidence, and optimism due to not feeling perfect may be more depressive and stressful. Self-esteem was found to have a full mediator role in the relationship between dependency and both depression and
\end{abstract}

\footnotetext{
* Esra Asici, Kilis 7 Aralik University, Muallim Rifat Education Faculty, Kilis, Turkey; esraasici01@gmail.com Halil Ibrahim Sari, University of Rochester, Warner School of Education, New York, USA; hisari87@gmail.com
} 


\section{Acta Educationis Generalis \\ Volume 12, 2022, Issue 1}

anxiety. The beliefs about the necessity of approval by others for being happy indirectly lead to worries about experiencing bad events in the future and being sad, unhappy, and depressed. These beliefs increase the negative self-judgments and cause losing self-confidence and underestimating the abilities and success. When the university students lose their self-esteem due to being disapproved by others, they may feel guilty, unhappy, depressive, and anxious. Self-esteem had a partial mediator role in the relationship between dependency and stress. Considering that stress is a reaction occurring when an individual feels threatened, it might be thought that the university students, who have beliefs about dependency, feel more threatened. The students who are not approved by others lose their self-esteem, so they may experience more stress. Finally, the increase in age led to a decrease in depression, anxiety, and stress. In addition to the developmental difficulties, the difficulties about university life may cause younger university students to experience more depression, anxiety, and stress.

Limitations: The data were collected from the students enrolled in the same university in the South-Eastern Anatolia Region of Turkey. The gender distribution of the participants was not balanced. The participants of this study were selected using the convenience sampling method. This study was designed quantitatively.

Conclusion: The results revealed that low self-esteem and the presence of dysfunctional attitudes were important risk factors in terms of university students' mental health. In order to prevent depression, anxiety, and stress in university students, the university counseling centers may organize individual or group counseling practices. These counseling practices should aim to support the development of self-esteem. Besides, psychoeducational programs aiming to increase self-esteem should be conducted.

Key words: depression, anxiety, stress, dysfunctional attitudes, selfesteem.

\section{Introduction}

During the university years, which is an important step in the transition from adolescence to adulthood, students feel under intense pressure due to a great variety of factors such as economic difficulties, academic duties, interpersonal relations, and changing lifestyle (Zeng, Wang, Xie, Hu, \& Reinhardt, 2019). While some students can cope with this pressure effectively, others may have emotional, social, or academic difficulties (Boyraz, Horne, Owens, \& Armstrong, 2016). For this reason, many university students' mental health may be at risk.

The most common mental health problems seen in university students are depression, anxiety, and stress (Beiter et al., 2015). According to the studies conducted over the last decade, the prevalence of depression among university students ranges from $23.2 \%$ to $79 \%$, the prevalence of anxiety from $17.1 \%$ to 


\section{Acta Educationis Generalis \\ Volume 12, 2022, Issue 1}

$86.3 \%$, and the prevalence of stress from $20.2 \%$ to $72.9 \%$ (Bilican, Yapici, \& Kutlu, 2016; Cam \& Top, 2018; Ediz, Ozcakir, \& Bilgel, 2017; Mahmoud, Staten, Hall, \& Lennie, 2012; Ozen, Ercan, Irgil, \& Sigirli, 2010; Saleh, Camart, \& Romo, 2017; Salem, Allah, \& Said, 2016; Savc1 \& Aysan, 2014; Zeng et al., 2019).

When depression, anxiety, and stress symptoms intensify and persist for a long time, they disrupt the functionality of university students in different areas of life; and they also prevent them from living a healthy, successful, productive, and happy life (Arslan \& Örnek, 2018). For example, it is known that university students with depressive symptoms exhibit more smoking and alcohol use behaviors (Arslan, Ayranci, Unsal, \& Arslantas, 2009) and are prone to suicide (Dvorak, Lamis, \& Malone, 2013). It is emphasized that university students with high anxiety levels are also less satisfied with their lives (Mahmoud et al., 2012). Depression, anxiety, and stress negatively affect especially the academic life of university students. High depression, anxiety, and stress cause their academic performance to decrease (Owens, Stevenson, Hadwin, \& Norgate, 2012; Salem et al., 2016). So much so that high depression can result in school absenteeism (Finning et al., 2019) and even school dropout (Boyraz et al., 2016).

Considering their prevalence rates and the negative results they cause, it is understood that depression, anxiety, and stress are mental problems that should be overemphasized in regard to university students. Young people who are university students today will shape the future of the countries by taking active roles in different fields such as education, health, engineering, economics, arts or politics. In other words, protecting the mental health of today's youth is critical for the future of the countries (Mehešová, 2017). In higher education, psychological counseling and guidance services should focus on preventing the occurrence of depression, anxiety, and stress in university students. In order to prepare effective preventive psychological counseling and guidance practices, it is necessary to determine the risk factors related to depression, anxiety, and stress. In line with this necessity, this study focuses on the factors that pose a risk of depression, anxiety, and stress in an attempt to lead the psychological counseling and guidance services in higher education.

One of the risk factors that leave university students vulnerable to depression, anxiety, and stress is the dysfunctional attitudes or distorted thinking, which cognitive therapists put emphasis on. According to cognitive therapists, what impairs individuals' mental health is the disorders in their mindset (İkiz, 2016). Dysfunctional attitudes refer to these disorders in the individual's mindset; in other words, they are unrealistic evaluations and beliefs about oneself, the world, and the future (Beck, 2001). The foundations of the individual's beliefs are laid in early childhood years. For example, while children who are supported and loved by their parents develop positive beliefs about themselves, such as "I am loved" or "I am sufficient"; those deprived of support and love may develop negative beliefs, such as "I am not worthy of love" or "I am insufficient.". These 


\section{Acta Educationis Generalis \\ Volume 12, 2022, Issue 1}

developmental experiences in the early childhood years, together with the critical events and traumatic experiences exposed in later years, constitute a system of beliefs known as cognitive schemas (Sharf, 2014). Beliefs that do not reflect the truth and are rigid, extreme, and over-generalized lead to extreme emotions, prevent individuals from demonstrating their performance (Savaşır, Boyacıŏlu, \& Kabakçı, 1996), and have an influence in all periods of their life (Sharf, 2014). Dysfunctional thinking patterns, such as arbitrary inference, selective abstraction, over-generalization, magnification, minimization, personalization, labeling, and polarization, which cause individuals to misinterpret events (Corey, 2005), are considered as the source of all psychological disorders (Beck, 2001).

Weissman and Beck (1978) address dysfunctional attitudes in two dimensions: perfectionism/focusing on performance and dependency. Perfectionism involves the beliefs that the individual should be the best in everything he/she does, and the concerns about the negative evaluations of other people about his/her performance. Dependency, on the other hand, refers to the beliefs that one should get the appreciation and approval of other people in order to be happy (de Graaf, Roelofs, \& Huibers, 2009; Şahin \& Batıgün, 2016). In this study, dysfunctional attitudes are discussed within the framework of this twodimensional classification.

Since dysfunctional attitudes emerged through the cognitive behavioral therapy approach developed by Beck for the treatment of depression (Beck, Rush, Shaw, \& Emery, 1979), they are mostly associated with depression, and it is emphasized that dysfunctional attitudes leave the person vulnerable to depression (Horiuchi, Aoki, Takagaki, \& Shoji, 2017; Tehranchi, Neshatdoost, \& Amiri, 2019). However, there are close relationships between depression, anxiety, and stress (Zeng et al., 2019). Therefore, it can be expected that dysfunctional attitudes are associated with anxiety and stress as well as depression. Indeed, some studies have revealed that being a perfectionist (Pirbaglou et al., 2013) and the need for being approved by others (Steers et al., 2016; Yang et al., 2014) increase anxiety and stress. The beliefs regarding the necessity of being the best in everything and always getting the approval of others can cause an individual to be constantly preoccupied with thoughts such as "What if I cannot achieve the best?" or "What if people don't like me?" and consequently to experience more anxiety and stress. In this context, having dysfunctional attitudes related to perfectionism and dependency may be an important risk factor for the emergence of depression, anxiety, and stress in university students.

Another factor that poses a risk to the mental health of university students is low self-esteem. Self-esteem, which is considered as a central element of daily life (Kernis, 2003), includes one's evaluations of self-concept and emotional reactions about one's own characteristics (Burger, 2006). While people with high self-esteem make positive evaluations about their characteristics, people 


\section{Acta Educationis Generalis \\ Volume 12, 2022, Issue 1}

with low self-esteem evaluate their characteristics negatively. High self-esteem is associated with self-confidence; optimism; risk-taking; being open to new experiences; a clear, consistent, and determined sense of self; desire for success; and resistance to challenges. Low self-esteem, on the other hand, is associated with lack of self-confidence, underestimating one's own abilities, not accepting the success, avoiding new experiences and risks, difficulty in making decisions, and despair in case of failure (André \& Lelord, 2002; Baumeister, 1993; Burger, 2006; Plummer, 2005). Additionally, it is emphasized that individuals with low self-esteem fail to cope with stress (Avşaroğlu \& İdayeva, 2020).

It can be thought that young people with low self-esteem experience more anxiety and stress in fulfilling their responsibilities regarding university life as they are not self-confident, and they are more vulnerable to emergence of depression, anxiety, and stress because they cannot effectively cope with the difficulties they face. Previous studies have also revealed that as the individuals' self-esteem decreases, their depression (Bajaj, Robins, \& Pande, 2016; Chai et al., 2020; Sowislo \& Orth, 2013), anxiety (Bajaj et al., 2016; Sowislo \& Orth, 2013), and stress levels (Saleh et al., 2017) increase. Considering the current findings in the literature, it was expected in the current study that the decrease in self-esteem would cause an increase in depression, anxiety, and stress.

Previous studies have clearly proven that dysfunctional attitudes and low selfesteem are important risk factors for depression, anxiety, and stress. Previous studies have also addressed direct relationships between variables. However, dysfunctional attitudes may have an indirect effect of increasing depression, anxiety, and stress by causing a decrease in self-esteem. There are some findings in the literature that the increase in the dysfunctional attitudes causes a decrease in self-esteem (Ashby \& Rice, 2002; Yuchang, Cuicui, Junxiu, \& Junyi, 2017). Therefore, a university student who believes in the necessity of being the best in everything and always being approved by others may start making negative selfevaluations when these requirements are not fulfilled. They may also become more prone to experience depression, anxiety, and stress, as they are involved in negative self-evaluations. When the bilateral relationships between variables revealed by the previous studies are evaluated together, it is possible that selfesteem has a mediating role in the relationship between dysfunctional attitudes and depression, anxiety, and stress. For this reason, this study also examines the mediating effect of self-esteem, unlike the previous studies that examined the bilateral relationships between variables.

Age may be another factor that poses a risk of depression, anxiety, and stress in university students. Since they still have the developmental characteristics of adolescence and have less life experience, it can be thought that younger university students have more difficulties overcoming problems and coping with difficulties. Thus, being young can pose a risk of depression, anxiety, and stress. As a matter of fact, some previous studies have shown that younger university students experience more depression, anxiety, and stress (Mahmood et al., 


\section{Acta Educationis Generalis \\ Volume 12, 2022, Issue 1}

2012). Nevertheless, there are also findings indicating that being young is protective against depression, anxiety, and stress (Salam et al., 2016). Due to the inconsistencies between research findings, more research should be conducted in order to identify the effect of age. To that end, the effect of age on depression, anxiety, and stress is examined in the study.

In the light of the above information, the aim of this study is to examine the direct relationships between dysfunctional attitudes (perfectionism and dependency) and depression, anxiety, and stress, and the mediating role of selfesteem in these relationships. It is thought that determining the mediating role of self-esteem will help to better understand depression, anxiety, and stress in university students and shed light on preventive studies. Within the scope of the study, direct effect of age on the university students' symptoms of depression, anxiety, and stress symptoms is also tested. Since the previous findings related to the effect of age are not consistent with each other, the result to be obtained will contribute to a better understanding of the subject. In this direction, this study seeks answers to the following research questions:

1. What are the magnitude and direction of the effects of perfectionism on depression, anxiety, and stress?

2. What are the magnitude and direction of the effects of dependency on depression, anxiety, and stress?

3. What are the magnitude and direction of the effects of age on depression, anxiety, and stress?

4. What is the mediating effect of self-esteem in the relationships between perfectionism and dependency, and depression, anxiety, and stress?

\section{Method}

\subsection{Study design}

This relational study aims to examine the relationships between dysfunctional attitudes, depression, anxiety, stress, self-esteem, and age using path analysis technique.

\subsection{Participants}

The participants of the study consisted of 407 undergraduates, $70.5 \%(\mathrm{n}=287)$ females and $29.5 \%(n=120)$ males, selected using the convenience sampling method, who were studying at the faculty of education, faculty of science and letters, faculty of theology and school of physical education and sports in a state university in the Southeastern Anatolia Region of Turkey in the academic year 2019-2020. The participants' ages ranged from 18 to 48 years $(\chi$ age $=21.45$, SDage $=2.76) .21 .4 \%(n=87)$ of the participants were freshmen, $34.6 \%(n=141)$ were sophomores, $22.4 \%(n=91)$ were juniors, and $21.6 \%(n=88)$ were seniors. $20.3 \%$ ( $n=83$ ) of them defined the economic status of their family as low, $76.9 \%$ $(\mathrm{n}=313)$ as medium, and $2.7 \%(\mathrm{n}=11)$ as high. 


\section{Acta Educationis Generalis \\ Volume 12, 2022, Issue 1}

\subsection{Data collection tools}

\subsubsection{Demographic Information Form}

Data about the participants' age, gender, class level, the faculty they study at, and perceptions regarding the economic situation of their families were collected using a demographic information form created by the researchers.

\subsubsection{Depression Anxiety Stress Scale-21 (DASS-21)}

Original DASS was developed by Lovibond and Lovibond (1995) as a 42-item, 4-point Likert type scale $(0=$ Not suitable for me at all, $3=$ Completely suitable for me) to evaluate three elements of negative mood (depression, anxiety, stress). Antony, Bieling, Cox, Enns, and Swinson (1998) found that the 21-item short form of DASS was also a valid and reliable measurement tool. In the adaptation study carried out by Yıldırım, Boysan, and Kefeli (2018), it was determined that the Turkish form preserved its original three-factor structure (S-B $\chi 2=379.787$, $\mathrm{df}=186, \mathrm{p}<.001, \mathrm{RMSEA}=.058, \mathrm{CFI}=.929$, TLI=.920, SRMR=.044) and the Cronbach's alpha internal consistency coefficients of DASS-21 were found as .89 for the sub-dimension "depression", .87 for the sub-dimension "anxiety", and .90 for the sub-dimension "stress". Within the scope of this study, Cronbach's alpha internal consistency coefficients were calculated as $.85, .82$, and .83 , respectively. There is no total score for the overall scale, and the total scores for each sub-dimension are calculated separately. The scores for each sub-dimension are in the range of $0-21$. The higher the score, the more the individual experiences depression, anxiety, or stress.

\subsubsection{Dysfunctional Attitudes Scale Short Form (DAS-17)}

Original DAS was developed by Weissman and Beck (1978) as a 40-item, 7point Likert type scale (1-I totally disagree, 7-I totally agree) in two separate forms, i.e. $\mathrm{A}$ and $\mathrm{B}$, in order to evaluate the dysfunctional attitudes associated with depression. De Graaf, Roelofs, and Huibers (2009) selected 17 items from the form A and created the 17-item short form of DAS. The scale consists of two sub-dimensions: perfectionism/focusing on performance $(11$ items $)$ and dependency ( 6 items). The results of the explanatory and confirmatory factor analysis, which was conducted within the scope of the Turkish adaptation study carried out by Şahin and Batigün (2016), revealed that the two-dimensional structure of the scale was preserved in the Turkish version $(\chi 2=352.60(\mathrm{p}<.001)$, $\chi 2 / \mathrm{df}=3.14, \mathrm{RMSEA}=.06, \mathrm{GFI}=.92$, AGFI $=.89$, SRMR $=.06$, ECVI=.92). In the adaptation study, Cronbach's alpha internal consistency coefficients of the Turkish form of the DAS-17 were found as .77 for the sub-dimension "perfectionism" and .74 for the sub-dimension "dependency". In the present study, the Cronbach's alpha internal consistency coefficients were calculated as .83 for perfectionism and .77 for dependency. The scores for the sub-dimension "perfectionism" range from 11 to 77 , and the scores for the sub-dimension 


\section{Acta Educationis Generalis \\ Volume 12, 2022, Issue 1}

"dependency" vary between 6 and 42. The higher the scores, the higher the perfectionism or dependency.

\subsubsection{Rosenberg Self-Esteem Scale (RSES)}

Originally developed by Rosenberg (1963), RSES consists of 63 items and 12 sub-dimensions. The first dimension evaluating self-esteem is a 4-point Likert type scale (1 - So wrong, 4 - So true) and consists of 10 items. The scale was adapted to Turkish by Çuhadaroğlu (1986). In the adaptation study, the testretest reliability coefficient of the scale was found as .75. In the present study, the Cronbach's alpha internal consistency coefficient of the scale was calculated as .84 . The scores for the scale vary between 10 and 40 , and the higher the score, the higher the self-esteem.

\subsection{Data collection and analysis}

Before the data was collected, necessary application permissions were obtained from the Ethics Committee of the university, where the data would be collected (Document number of the ethics committee approval: 20.03.2020-E.184E.1962). Afterwards, the scale forms were transferred to the online environment via Google Forms application, and the online questionnaire link was shared with the students by the researcher via WhatsApp application in the classroom environment. Before starting to fill out the questionnaire, the researcher verbally informed the students about the purpose of the study and explained that participation in the study was completely voluntary, and they could refuse to fill out the questionnaire during the data collection phase. It took approximately 20 minutes to complete the questionnaires.

After reviewing the current literature, the proposed model shown in Figure 1 was established. According to this model, perfectionism, dependency, and age were the exogenous variables; depression, anxiety, and stress were the endogenous variables; and self-esteem was the mediating variable. The study hypothesized that there were direct effects of perfectionism and dependency on depression, anxiety, and stress, and indirect effects through self-esteem, and direct effects of age on depression, anxiety, and stress. Hypotheses were tested via path analysis.

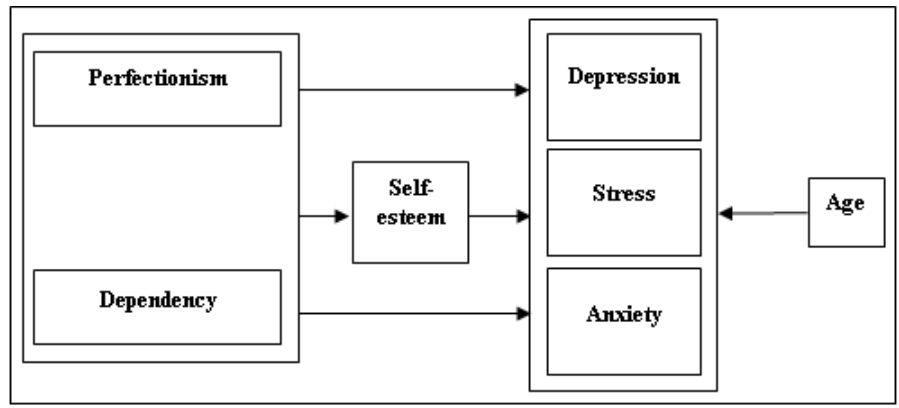

Figure 1. Hypothesized path model. 


\section{Acta Educationis Generalis \\ Volume 12, 2022, Issue 1}

In the study, total scores for depression, anxiety, stress, perfectionism, dependency, and self-esteem were calculated, and the scores of all the variables together with age were used in the analysis as a continuous variable. Mplus 7 (Muthen \& Muthen, 1998-2012) statistical program was used to analyze the data. Although the hypothesized model perfectly fit the data, as some effects were not statistically significant (greater than .05), this model was reviewed, and the selected model shown in Figure 2 was obtained. Correlation values between variables, means, and standard deviations of the total scores of the variables are given in Table 1. Bootstrap method was used with 1000 trials in path analysis, and $90 \%$ confidence intervals for direct, indirect, and total effects are given in Table 2.

Table 1

Correlations among variables, means and standard deviations

\begin{tabular}{lllllllll}
\multicolumn{1}{c}{ Variables } & \multicolumn{1}{c}{} & $\underline{1}$ & $\underline{3}$ & $\underline{3}$ & $\underline{4}$ & $\underline{5}$ & $\underline{6}$ & $\underline{7}$ \\
1.Age & -- & & & & & & \\
2.Perfectionsim & -.05 & - & & & & & \\
3.Dependency & $-.11^{*}$ & $-.48^{*}$ & -- & & & & \\
4.Self-esteem & -.00 & $-.26^{*}$ & $-.35^{*}$ & -- & & & \\
5.Depression & $-.14^{*}$ & $.27^{*}$ & $.21^{*}$ & $-.36^{*}$ & -- & & \\
6.Anxiety & $-.20^{*}$ & $.15^{*}$ & $.19^{*}$ & $-.26^{*}$ & $.70^{*}$ & -- & \\
7.Stress & $-.17 *$ & $.25^{*}$ & $.25^{*}$ & $-.28^{*}$ & $.77^{*}$ & $.74^{*}$ & -- \\
Mean & 21.45 & 27.74 & 20.62 & 30.61 & 8.31 & 6.83 & 9.00 \\
Standard Deviation & 2.76 & 12.39 & 7.87 & 4.94 & 4.62 & 4.17 & 4.28 \\
\hline * $p<.05$ & & & & & & &
\end{tabular}

\section{Findings}

\subsection{Findings related to model-data fit}

Model-data fit statistics for the hypothesized model given in Figure 1 were found as $\chi 2 / \mathrm{df}=0.32 / 1, \mathrm{p}=.57$, CFI $=1.00$, TLI $=1.00$, SRMR $=.00$. According to these findings, the hypothesized model perfectly fit the data (Hooper, Coughla, \& Mullen, 2008; Kline 2005). Some effects (paths) in this model were excluded from the model because they were not statistically significant. Model fit statistics for the selected path analysis given in Figure 2 were found as $\chi 2 / \mathrm{df}=5.11 / 4, \mathrm{p}=.27, \mathrm{CFI}=.99, \mathrm{TLI}=.99, \mathrm{SRMR}=.02$. These values indicate that the selected path analysis model fit the data very well. The variance ratios explained by depression, anxiety, stress, and self-esteem were statistically significant at the level of .05 and found as .17, .11,.12, and .14, respectively.

\subsection{Findings related to direct, indirect, and total effects}

Perfectionism. Perfectionism was found to have statistically significant total effects on self-esteem (-.05), depression (.06), and stress (.04). The whole .05 


\section{Acta Educationis Generalis \\ Volume 12, 2022, Issue 1}

effect on self-esteem was a direct effect. .04 of the total effect of .06 on depression was a direct effect and .02 was an indirect effect. However, only the direct effect was statistically significant, but the indirect effect was not. .03 of the total effect of .04 on stress was a direct effect and .01 was an indirect effect. However, only the direct effect was statistically significant, but the indirect effect was not. Perfectionism had no direct effect on anxiety, but had an indirect effect through self-esteem; however, this was not a significant effect. According to the findings, the effects of perfectionism on depression, self-esteem, and stress were quite close to each other and small.

Dependency. Dependency was found to have statistically significant total effects on self-esteem (-.18), depression (.05), anxiety (.04), and stress (.07). The whole effect of -.18 on self-esteem was a direct effect. The total effects of .05 on depression and .04 on anxiety were all indirect effects. Indirect effects were through self-esteem. Therefore, self-esteem was found to fully mediate the effect between dependency, and depression and anxiety. .04 of the .07 effect on stress was a direct effect and .03 was an indirect effect. Both the direct and indirect effects were significant, and the indirect effect was through self-esteem. Accordingly, dependency had a greater effect on self-esteem than perfectionism, and self-esteem mediated between dependency, and depression, anxiety, and stress.

Age. Based on the proposed model, age was found to have statistically significant total effects on depression (-.22), anxiety (-.29), and stress (-.22). All the effects were direct, and age did not have any indirect effect on these three endogenous variables. The effect of age on anxiety was greater than its effect on depression and stress. In addition, it was observed that as the age increased, the students' depression, anxiety, and stress levels decreased.

Self-esteem. Based on the model, self-esteem was found to have statistically significant total effects on depression (-.30), anxiety (-.21), and stress (-.20). All the effects were direct, and self-esteem did not have any indirect effect on these three endogenous variables. The effect of self-esteem on depression was greater than its effect on anxiety and stress. In addition, it was observed that as the selfesteem increased, the students' depression, anxiety, and stress levels decreased.

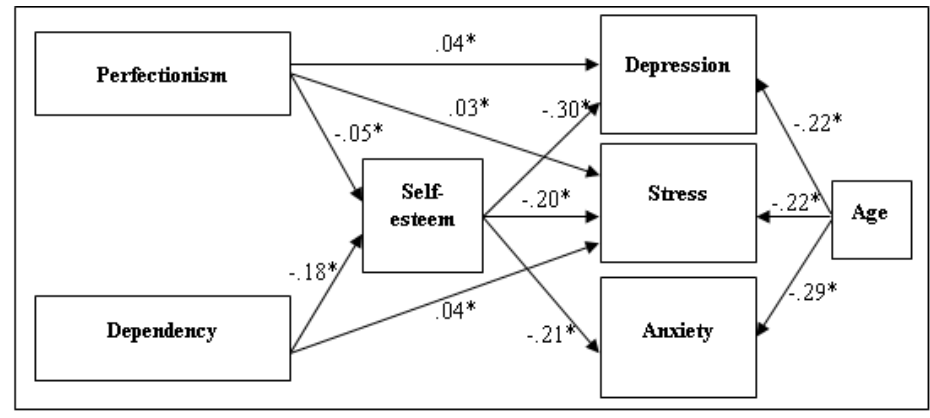

Figure 2. Selected path model 


\section{Acta Educationis Generalis \\ Volume 12, 2022, Issue 1}

\section{Table 2}

The sizes and $90 \%$ confidence intervals of total, direct, and indirect effects of variables in the selected path model

\begin{tabular}{|c|c|c|c|c|}
\hline \multicolumn{5}{|c|}{ Endogenous Variables } \\
\hline$\frac{\text { Exogenous }}{\text { Variables }}$ & $\underline{\text { Self-esteem }}$ & $\underline{\text { Depression }}$ & $\underline{\text { Anxiety }}$ & $\underline{\text { Stress }}$ \\
\hline \multirow[t]{3}{*}{$\overline{\text { Perfectionism }}$} & $-.05 *[-.09,-.01]$ & $.04 *[.02, .06]$ & -- & $.03 *[.02, .06]$ \\
\hline & -- & $.02[.00, .03]$ & $.01[.00, .02]$ & $.01[.00, .03]$ \\
\hline & $\mathbf{- . 0 5} *[-.09,-.01]$ & $.06 *[.03, .08]$ & $.01[.00, .02]$ & $.04 *[.03, .08]$ \\
\hline \multirow[t]{3}{*}{ Dependency } & $-.18 *[-.24,-.12]$ & -- & -- & $.04 *[.02, .06]$ \\
\hline & -- & $.05 *[.03, .08]$ & $.04 *[.02, .06]$ & $.03 *[.00, .03]$ \\
\hline & $-.18 *[-.24,-.12]$ &. $\mathbf{0 5} *[.03, .08]$ & $.04 *[.02, .06]$ & $\mathbf{. 0 7} *[.03, .08]$ \\
\hline \multirow[t]{3}{*}{ Age } & -- & $-.22 *[-.36,-.12]$ & $-.29 *[-.40,-.20]$ & $-.22 *[-.36,-.12]$ \\
\hline & -- & -- & -- & -- \\
\hline & -- & $-.22 *[-.36,-.12]$ & $-.29 *[-.36,-.20]$ & $-.22 *[-.36,-.12]$ \\
\hline \multirow[t]{3}{*}{ Self-esteem } & -- & $-.30 *[-.38,-.23]$ & $-.21 *[-.28,-.14]$ & $-.20 *[-.27,-.12]$ \\
\hline & -- & -- & -- & -- \\
\hline & -- & $-.30 *[-.38,-.23]$ & $-.21 *[-.28,-.14]$ & $\mathbf{- . 2 0} *[-.27,-.12]$ \\
\hline
\end{tabular}

Note. Direct effects in regular text, indirect effects in italics, and total effects in bold. The symbol - means the effect is not in the model; ${ }^{*} \mathrm{p}<.05$; all effects are unstandardized effects.

\section{Discussion}

The findings of the study revealed that dysfunctional attitudes related to perfectionism and dependency, low self-esteem, and being young were important risk factors for depression, anxiety, and stress, which are common in university students (Beiter et al., 2015). Accordingly, it is important that university psychological counseling and guidance centers organize studies aiming to protect the mental health of the students, who are younger and have dysfunctional attitudes and low self-esteem.

The first finding is that the increase in self-esteem decreased the university students' symptoms of depression, anxiety, and stress. This finding is in parallel with the findings of previous studies, which revealed that self-esteem was negatively associated with depression (Bajaj et al., 2016; Chai et al., 2020; Sowislo \& Orth, 2013), anxiety (Bajaj et al., 2016; Sowislo \& Orth, 2013), and stress (Saleh et al., 2017). Accordingly, it can be asserted that having positive evaluations regarding own personality traits (Burger, 2006) is an important protective factor for the university students to keep themselves away from mental problems. It is emphasized that an individual with high self-esteem feels more confident, can have an optimistic view about events, likes new experiences, does not hesitate to take risks, and prefers to resist instead of giving up immediately in the face of difficulties or failures (André \& Lelord, 2002; Baumeister, 1993; Burger, 2006; Plummer, 2005). Therefore, it can be thought 


\section{Acta Educationis Generalis \\ Volume 12, 2022, Issue 1}

that a university student with high self-esteem is more confident, more optimistic, makes an attempt to solve problems, and in case of failure, attempts to apply new solutions instead of giving up and giving into negative feelings about dealing with financial difficulties, concerns for the future, academic pressures, problems in emotional relations, in friendships or family problems that they face during university years. In other words, high self-esteem can help university students cope with difficulties more effectively; thus, it contributes to keeping away from negative emotions such as depression, anxiety, and stress. In the study, it was also found that the effect of self-esteem on depression was greater than its effect on anxiety and stress. Accordingly, it can be asserted that low self-esteem is more of an important risk factor for the emergence of depression rather than anxiety and stress.

The second finding is that the university students' dysfunctional attitudes related to perfectionist and dependency affected their self-esteem directly in a negative way. In other words, their beliefs that they should be perfect in everything they do, and it is not possible to be happy without the approval of others (de Graaf et al., 2009; Şahin \& Batıgün, 2016) made it difficult for the university students to respect themselves and make positive self-evaluations. This result supports the previous findings (Ashby \& Rice, 2002; Yuchang et al., 2017) showing that an increase in dysfunctional attitudes leads to a decrease in self-esteem. Accordingly, beliefs about perfectionism and gaining the approval of others are important risk factors for low self-esteem in university students. It can be asserted that as their beliefs about being perfect and gaining the approval of others increase, the behaviors indicating low self-esteem are more likely to arise in university students, such as lack of self-confidence, underestimating own abilities, not accepting own successes, abstaining from new experiences, avoiding taking risks, difficulty in making decisions, and despair in case of failure (André \& Lelord, 2002; Baumeister, 1993; Burger, 2006; Plummer, 2005). In the current study, it was also found that the effect of dependency on self-esteem was greater than that of perfectionism. Accordingly, it can be thought that university students' self-evaluations are mostly shaped within the frame of the respect, value, and importance attached by others. In the increase of the university students' self-esteem, it is important that they feel admired and appreciated by others rather than achieve perfection in everything they do. This may be an indication that their personalities are still not fully formed, and they still have the characteristics of adolescence.

The third finding is that the university students' perfectionist attitudes had a direct effect on the increase in their depression and stress levels. This result, which is in line with the findings of the previous studies (Kaya et al., 2019), shows that the university students' beliefs that they should be the best in everything they do and their concerns regarding the negative evaluations of other people about their performance (de Graaf et al., 2009; Şahin \& Batıgün, 2016) are among the main risk factors for depression and stress symptoms. In addition, 


\section{Acta Educationis Generalis \\ Volume 12, 2022, Issue 1}

the findings showed that the direct effect of perfectionist attitudes on anxiety was not significant. The university students, who believe they must be perfect, may encounter a great variety of difficulties that prevent them from achieving perfection or make it difficult for them. These difficulties can lead to emotional, physical, and behavioral stress reactions. University students, who cannot achieve the desired perfection for various reasons, may get disappointed and show depressive symptoms such as sadness, unhappiness, guilt, and pessimism because their expectations are not satisfied. However, university students' expectations of being the best do not have an impact on their concerns about the bad things possible to occur in the future.

The fourth finding is that although dependency did not have a direct effect on depression and anxiety, it affected them indirectly through self-esteem in a positive way. The effect of dependency on depression and anxiety was indirect and totally through self-esteem. In other words, self-esteem played a full mediating role in the relationship between dependency, and depression and anxiety. Accordingly, the beliefs regarding that it is a necessity to be admired and appreciated by others in order to be happy (de Graaf et al., 2009; Şahin \& Batıgün, 2016) do not directly cause the university students to be concerned about the bad events that might occur in the future or to show depressive symptoms such as long-term sadness, unhappiness, guilt, pessimism, despair, and lack of energy. However, it can be asserted that these beliefs increase the tendency to make negative self-evaluation, lose self-confidence, underestimate own abilities and achievements, and have difficulty in making decisions (André \& Lelord, 2002; Baumeister, 1993; Burger, 2006; Plummer, 2005). University students, who lose their self-esteem as they do not receive the admiration and appreciation they expect from others, may feel guilty, be pessimistic and unhappy on the one hand, and be worried about the future bad events on the other.

The fifth finding is that dependency positively affected stress directly as well as indirectly through self-esteem. Thus, self-esteem plays a partial mediating role in the relationship between dependency and stress. Considering that stress is a reaction that occurs when the individual feels under threat, it can be thought that university students who believe that they need to get the appreciation and approval of the other people for being happy (de Graaf et al., 2009; Şahin ve Batıgün, 2016) feel more threatened. The fact that these students' selfevaluation, i.e. their self-esteem, depends on the appreciations and approvals of others also exerts an influence on the stress they experience. It is possible that the university students who feel disapproved by others get more stressed, as their self-esteem decreases. As can be seen, while perfectionism has a direct effect on depression, dependency affects depression through self-esteem. This result supports the findings of Horiuchi et al. (2017) that perfectionist attitudes are more effective on depression compared to dependency attitudes. 


\section{Acta Educationis Generalis \\ Volume 12, 2022, Issue 1}

The final finding is that the students' depression, anxiety, and stress levels decreased as their age increased. This result is consistent with the findings of previous studies (Mahmood et al., 2012) showing that younger university students have more depression, anxiety, and stress symptoms than the older ones. The reason why younger university students show more depression, anxiety, and stress symptoms may be associated with developmental characteristics. It can be thought that at the ages of 18-19, which can be defined as late adolescence, university students cannot fully adapt themselves to the rapid changes occurring in their adolescence and begin higher education with intense and complex emotions. Their developmentally complex and uncertain environment may also make it difficult for them to adapt themselves to the university life and fulfill its requirements. Younger university students who have difficulties regarding university life as well as developmental difficulties may show more intense symptoms of depression, anxiety, and stress. It can be thought that as the university students get older and step from adolescence to adulthood, they begin to move away from these negative moods.

This study has some limitations. First, the data were collected from the students enrolled in the same university in the Southeastern Anatolia Region of Turkey. In the future, renewal of the study with the participation of students from different regions and different cities may help to reach more general results. Second, when the distribution of the students participating in the study is examined by gender, it can be seen that the number of female $(n=287)$ was more than twice the number of male $(n=120)$. Future studies can be carried out on a more gender-balanced study group. Third, the information on the demographic characteristics of the students was limited in this study. However, factors such as having a job, housing conditions, and studying at a second university may also have an effect on the university students' level of depression, anxiety, and stress. For example, depression, anxiety, and stress symptoms of the students who live with their family may differ from those of the university students who are away from their family. Or the students, who have to study at a second university after completing a bachelor's program because they cannot begin a career, may have a higher level of depression, anxiety, and stress. Future studies can be organized by paying attention to the factors such as having a job, housing conditions, and studying at a second university. Fourth, the participants of this study were selected using the convenience sampling method. In the future, studies based on random sampling method may be carried out. Fifth, this study was designed quantitatively. Future studies to be designed using a mixed method can contribute to a better understanding of the subject.

\section{Conclusion}

It is understood from the results of the study that the presence of low self-esteem and dysfunctional attitudes related to perfectionism and dependency are important risk factors for the mental health of university students. On this basis, 


\section{Acta Educationis Generalis \\ Volume 12, 2022, Issue 1}

in order to prevent the emergence of depression, anxiety, and stress symptoms in university students, it is recommended to conduct screening studies at universities to identify the students with dysfunctional attitudes, and to apply psycho-educational programs to help the students who are found to have beliefs regarding perfectionism and dependency develop healthier beliefs. Besides, individual and group counseling applications can be beneficial for the students with low self-esteem. Focusing on dysfunctional attitudes in studies towards improving self-esteem will produce effective results. Since it was determined that self-esteem had a mediating role in the effect of dependency on depression, anxiety, and stress, it is important to improve self-esteem of the students who especially have dysfunctional attitudes related to dependency. As the foundation of dysfunctional attitudes lies in early childhood experiences, informing parents about healthy child rearing attitudes will contribute to children's being mentally healthier adults. There may be other psychological variables that trigger the emergence of depression, anxiety, and stress. Expanding the scope of this study in the future in a way to include other psychological variables affecting depression, anxiety, and stress may make a significant contribution to the literature. For example, traumatic experiences can also have an impact on depression, anxiety, and stress symptoms. In the future, researchers can examine whether traumatic experiences have a mediating role in the effects of dysfunctional attitudes and self-esteem on depression, anxiety, and stress.

\section{References}

Andre, C., \& Lelord, F. (2002). Kendine saygı. İstanbul: İletişim Yayınları.

Antony, M. M., Bieling, P. J., Cox, B. J., Enns, M. W., \& Swinson, R. P. (1998). Psychometric properties of the 42-item and 21-item versions of the depression anxiety stress scales in clinical groups and a community sample. Psychological Assessment, 10(2), 176-181.

Arslan, G., Ayranci, U., Unsal, A., \& Arslantas, D. (2009) Prevalence of depression, its correlates among students, and its effect on health-related quality of life in a Turkish university, Upsala Journal of Medical Sciences, 114(3), 170-177. http://dx.doi.org/10.1080/ 03009730903174339

Arslan, Ü., \& Örnek, B. Y. (2018). Psikolojik bozukluklar ve tedavisi. In Ş. Işık (Ed.), Psikolojiye Giriş (pp. 478-521). Ankara: Pegem Akademi.

Ashby, J. S., \& Rice, K. G. (2002). Perfectionism, dysfunctional attitudes, and self-esteem: A structural equations analysis. Journal of Counselling ve Development, 80(2), 197-203.

Avşaroğlu, S., \& İdayeva, A. (2020). Üniversite öğrencilerinin benlik saygılarının stresle başa çıkma tutumlarını yordama gücü. MANAS Sosyal Araştırmalar Dergisi, 9(1), 411-422.

Bajaj, B., Robins, R. W., \& Pande, N. (2016). Mediating role of self-esteem on the relationship between mindfulness, anxiety, and depression. Personality and Individual Differences, 96, 127-131. http://dx.doi.org/10.1016/j.paid.2016.02.085

Baumeister, R. F. (1993). Identity, self-concept and self esteem. In R. Hogan, J. Jonhson, \& S. Briggs (Eds.), Handbok of personality sychology (pp. 681-710). California: Academic Press.

Beck, J. S. (2001). Bilişsel terapi temel ilkeler ve ötesi. Ankara: Türk Psikologlar Derneği Yayınlar1.

Beck, A. T, Rush, A. J., Shaw, B. F., \& Emery, G. (1979). Cognitive therapy of depression. New York: Guilford Press 


\section{Acta Educationis Generalis \\ Volume 12, 2022, Issue 1}

Beiter, R., Nash, R., McCrady, M., Rhoades, D., Linscomb, M., Clarahan, M., \& Sammut, S. (2015). The prevalence and correlates of depression, anxiety, and stress in a sample of college students. Journal of Affective Disorders, 173, 90-96. http://dx.doi.org/10.1016/j.jad.2014.10.054

Bilican, F. I., Yapici, A., \& Kutlu, M. O. (2016). A value model for depressive symptoms and hopelessness among university students in Turkey. Educational Sciences: Theory and Practice, 16(4), 1397-1418. http://dx.doi.org/10.12738/estp.2016.4.0112

Boyraz, G., Horne, S. G., Owens, A. C., \& Armstrong, A. P. (2016). Depressive symptomatology and college persistence among African American college students. The Journal of General Psychology, 143(2), 144-160. http://dx.doi.org/10.1080/00221309.2016.1163251

Burger, J. M. (2006). Kişilik. İstanbul: Kaknüs Yayınları.

Cam, H. H. \& Top, F. U. (2018). The relationship between health-related quality of life and prevalence of depressive symptoms among undergraduate nursing students in Turkey. Medicine Science, 7(1), 154-157. http://dx.doi.org/10.5455/medscience.2017.06.8714

Chai, L., Yang, W., Zhang, J., Chen, S., Hennessy, D. A., \& Liu, Y. (2020). Relationship between perfectionism and depression among Chinese college students with self-esteem as a mediator. OMEGA-Journal of Death and Dying, 80(3), 490-503. http://dx.doi.org/10.1177/0030222819849746

Corey, G. (2005). Psikolojik danışma, psikoterapi kuram ve uygulamaları. Ankara: Mentis Yayınc1lik

Çuhadaroğlu, F. (1986). Adolesanlarda benlik saygısı (Unpublished Master thesis). Ankara: Hacettepe University Medical Faculty.

de Graaf, L. E., Roelofs, J., \& Huibers, M. J. (2009). Measuring dysfunctional attitudes in the general population: The dysfunctional attitude scale (form A) revised. Cognitive Therapy and Research, 33(4), 345-355. http://dx.doi.org/10.1007/s10608-009-9229-y

Dvorak, R. D., Lamis, D. A., \& Malone, P. S. (2013). Alcohol use, depressive symptoms, and impulsivity as risk factors for suicide proneness among college students. Journal of Affective Disorders, 149(1-3), 326-334. http://dx.doi.org/10.1016/j.jad.2013.01.046

Ediz, B., Ozcakir, A., \& Bilgel, N. (2017). Depression and anxiety among medical students: Examining scores of the beck depression and anxiety inventory and the depression anxiety and stress scale with student characteristics. Cogent Psychology, 4(1), 1283829. http://dx.doi.org/10.1080/23311908.2017.1283829

Finning, K., Ukoumunne, O. C., Ford, T., Danielsson-Waters, E., Shaw, L., De Jager, I. R., \& Moore, D. A. (2019). The association between child and adolescent depression and poor attendance at school: A systematic review and meta-analysis. Journal of Affective Disorders, 245, 928-938. http://dx.doi.org/10.1016/j.jad.2018.11.055

Hooper, D., Coughlan, J., \& Mullen, M. R. (2008). Structural equation modelling: Guidelines for determining model fit. Electronic Journal of Business Research Methods, 6(1), 53-60.

Horiuchi, S., Aoki, S., Takagaki, K., \& Shoji, F. (2017). Association of perfectionistic and dependent dysfunctional attitudes with subthreshold depression. Psychology Research and Behavior Management, 10, 271-275.

İkiz, F. E. (2016). Psikolojik danı̧̧ma ve psikoterapide kuramlar ve yenilikçi yaklaşımlar. Ankara: Nobel Akademi.

Kaya, C., Chan, F., Brickham, D., Allen, M., Sarı, E., Şanal, M., \& Topal, T. (2019). Investigating the measurement structure of the Turkish version of the dysfunctional attitudes scale- 9 . Current Psychology, (online first). http://dx.doi.org/10.1007/s12144-019-00252-7

Kernis, M. H. (2003). Target article: Toward a conceptualization of optimal self-esteem. Psychological Injury, 14(1), 1-26.

Kline, R. B. (2005). Principles and practice of structural equation modeling. Guilford publications.

Lovibond, P. F., \& Lovibond, S. H. (1995). The structure of negative emotional states: Comparison of the depression anxiety stress scales (DASS) with the beck depression and 


\section{Acta Educationis Generalis \\ Volume 12, 2022, Issue 1}

anxiety inventories. Behaviour Research and Therapy, 33(3), 335-343. http://dx.doi.org/10.1016/0005-7967(94)00075-U

Mahmoud, J. S. R., Staten, R. T., Hall, L. A., \& Lennie, T. A. (2012). The relationship among young adult college students' depression, anxiety, stress, demographics, life satisfaction, and coping styles. Issues in Mental Health Nursing, 33(3), 149-156. http://dx.doi.org/10.3109/01612840.2011.632708

Mehešová, M. (2017). Social-emotional health of university students and the importance of its research. Acta Educationis Generalis, 7(2), 79-85. http://dx.doi.org/10.1515/atd-2017-0015

Muthén, L. K. \& Muthén, B. O. (1998-2012). Mplus user's guide. Seventh Edition. Los Angeles, CA: Muthén \& Muthén.

Owens, M., Stevenson, J., Hadwin, J. A., \& Norgate, R. (2012). Anxiety and depression in academic performance: An exploration of the mediating factors of worry and working memory. School Psychology International, 33(4), 433-449. http://dx.doi.org/10.1177/ 0143034311427433

Ozen, N.S., Ercan, I., Irgil, E., \& Sigirli, D. (2010). Anxiety prevalence and affecting factors among university students. Asia Pacific Journal of Public Health, 22(1), 127-133. http://dx.doi.org/10.1177/1010539509352803

Pirbaglou, M., Cribbie, R., Irvine, J., Radhu, N., Vora, K., \& Ritvo, P. (2013). Perfectionism, anxiety, and depressive distress: Evidence for the mediating role of negative automatic thoughts and anxiety sensitivity. Journal of American College Health, 61(8), 477-483. http://dx.doi.org/10.1080/07448481.2013.833932

Plummer, D. (2005). Helping adolescent and adults to build self-esteem: A photocoplable resource book. London, Philadephia: Jessica Kingsley Publishers.

Rosenberg, M. (1963). Parental interest and children's self-conceptions. Sociometry, 35-49.

Saleh, D., Camart, N., \& Romo, L. (2017) Predictors of stress in college students. Frontiers in Psychology, 8(19) 1-8. http://dx.doi.org/10.3389/fpsyg.2017.00019

Salem, G. M., Allah, M. B. A., \& Said, R. M. (2016). Prevalence and predictors of depression, anxiety and stress among Zagazig University students. The Medical Journal of Cairo University, 84(2), 325-334.

Savc1, M., \& Aysan, F. (2014). Üniversite öğrencilerinde algılanan stres düzeyi ile stresle başa çıkma stratejileri arasındaki ilişki. Uluslararası Türk Ĕgitim Bilimleri Dergisi, 3, 44-56.

Savaşır Boyacıoglu, G., \& Kabakçı, E. (1996). Bilişsel-davranışçı terapiler. Ankara: Türk Psikologlar Derneği Yayınları.

Sharf, R. S. (2014). Psikoterapi ve psikolojik danışma kuramları-Kavramlar ve örnek olaylar. Ankara: Nobel Yayınevi.

Sowislo, J. F., \& Orth, U. (2013). Does low self-esteem predict depression and anxiety? A metaanalysis of longitudinal studies. Psychological Bulletin, 139(1), 213-240. http://dx.doi.org/10.1037/a0028931

Steers, M. L. N., Quist, M. C., Bryan, J. L., Foster, D. W., Young, C. M., \& Neighbors, C. (2016). I want you to like me: Extraversion, need for approval, and time on Facebook as predictors of anxiety. Translational Issues in Psychological Science, 2(3), 283-293. http://dx.doi.org/10.1037/tps0000082

Şahin, N. H., \& Batıgün, A. D. (2016). Fonksiyonel olmayan tutumlar ölçeği kısa formu (FOTÖ17) uyarlama çalışması. Türk Psikoloji Yazıları, 19, 91-99.

Tehranchi, A., Neshatdoost, H. T., Amiri, S., \& Power, M. (2019). Analysis of emotions and dysfunctional attitudes in depression. Japanese Psychological Research, 61(3), 166-178. http://dx.doi.org/10.1111/jpr.12220

Yang, J., Yang, Y., Li, H., Hou, Y., Qi, M., Guan, L., ..., \& Pruessner, J. C. (2014). Correlation between self-esteem and stress response in Chinese college students: The mediating role of the need for social approval. Personality and Individual Differences, 70, 212-217. http://dx.doi.org/10.1016/j.paid.2014.06.049 


\section{Acta Educationis Generalis \\ Volume 12, 2022, Issue 1}

Yıldırım, A., Boysan, M., \& Kefeli, M. C. (2018). Psychometric properties of the Turkish version of the depression anxiety stress scale-21 (DASS-21). British Journal of Guidance ve Counselling, 46(5), 582-595. http://dx.doi.org/10.1080/03069885.2018.1442558

Yuchang, J., Cuicui, S., Junxiu, A., \& Junyi, L. (2017). Attachment styles and smartphone addiction in Chinese college students: the mediating roles of dysfunctional attitudes and selfesteem. International Journal of Mental Health and Addiction, 15(5), 1122-1134. http://dx.doi.org/10.1007/s11469-017-9772-9

Weissman, A. N. \& Beck, A. T. (1978). Development and validation of the dysfunctional attitude scale: A preliminary investigation. Annual Meeting of the American Educational Research Association, Toronto, Ontario.

Zeng, Y., Wang, G., Xie, C., Hu, X., \& Reinhardt, J. D. (2019). Prevalence and correlates of depression, anxiety and symptoms of stress in vocational college nursing students from Sichuan, China: a cross-sectional study. Psychology, Health and Medicine, 24(7), 798-811. http://dx.doi.org/10.1080/13548506.2019.1574358 